\title{
Sustainability of bioenergy in Malaysia with reference to palm oil biomass: adopting principles governing bioenergy policy in the UK
}

\author{
D. R. Abu Bakar \& G. Anandarajah \\ Energy Institute, Bartlett School of Environment, \\ Energy and Resources, University College London, UK
}

\begin{abstract}
In the UK, bioenergy is widely recognised in playing an important role if the country is expected to meet its low carbon objectives by 2050 and the EU Renewable Energy Directive objectives by 2020. The main driver for bioenergy development in the UK is thus to achieve this goal. The principles governing UK bioenergy policy are outlined in the UK Bioenergy Strategy (UKBS), whereby a sustainability criteria is recognised as key to distinguishing between the consistency of bioenergy production and its use with these principles. In comparison, Malaysia's bioenergy development has evolved from a different landscape, involving different drivers from social and economic development to protecting the environment. Recognising the palm oil sector as the main key producer of bioenergy, the aim of this paper is to (1) examine what could be the challenges and what could be achieved if Malaysia were to apply a principle-based approach in setting a strategic direction to guide bioenergy policy, similar to the UKBS in its current bioenergy policy; and (2) to assess, in general, the sustainability of Malaysian bioenergy with reference to the use of palm oil biomass by adopting the UK bioenergy sustainability criteria. This paper draws conclusions on the limitation capabilities of the palm oil sector with regard to the implementation of such policy approaches and the sustainability of palm oil bioenergy when using the UK sustainability criteria standard.

Keywords: Malaysia bioenergy, sustainability criteria, palm oil biomass.
\end{abstract}




\section{Introduction}

In the span of three decades, Malaysia has transformed itself from mainly an agricultural to an industrialised economy, with ambitions to become a highincome nation by 2020. According to UNDP [1], Malaysia ranked as the $26^{\text {th }}$ country in terms of largest greenhouse gas (GHG) emitter in the world based on its total emissions in 2004, and also among the Southeast Asian countries as the third largest emitter after Thailand (which ranked $22^{\text {nd }}$ ) and Indonesia (ranked $14^{\text {th }}$ ). In 2000, its GHG emission levels was reported about $223 \mathrm{Mt} \mathrm{CO}_{2}$ equivalent [2]. The country's energy-related $\mathrm{CO}_{2}$ emission accounted for $66 \%$ from the total GHG emission and possibly contributed by the economic development activities, as observed in most developing countries.

In combatting climate change, the UNFCCC has set its objective and principles for parties to protect the climate system on the basis of equity and in accordance with the concept of common but differentiated responsibilities and respective capabilities. In 2009, Malaysia announced a pledge to reduce its carbon emission intensity (per GDP) level by up to 40\% below 2005 levels by 2020 (COP 15 Meeting, UNFCCC) [2], an ambitious step only few nations in the Southeast Asia have committed to, such as Singapore and Indonesia. While Malaysia continues to maintain this position in subsequent negotiations, renewable energy and low carbon technology has become a focus in its long term energy planning. Bioenergy is one of the most versatile forms of low carbon and renewable energy as it can contribute towards energy generation and long term emission reductions across the energy spectrum of electricity, heat and transport. Among the low-risk energy deployment pathways for bioenergy are wastes, heat, (renewable) electricity and liquid transport fuel [3].

The Malaysian palm oil sector plays a strategic role as the key producer of bioenergy (i.e. generation of renewable electricity and in the production of liquid transport fuel (biodiesel)). This is due to the abundance of palm oil biomass resources (which comprises $80-90 \%$ of the total country's biomass; with 83 million dry tonnes of palm oil biomass and 60 million tonnes of palm oil mill effluent (POME) generated in 2012, and is expected to increase to 100 million dry tonnes and 70-110 million tonnes respectively by 2020 (driven by increases in yield)) [4-7], and palm oil as biodiesel feedstock. Palm oil biomass comprises of solid biomass (which consist of lignocellulosic residue such as fronds, trunks from the plantations, empty fruit bunch, mesocarp fibre and shells) and biogas (from palm oil mill effluent (POME); a liquid by-product generated from the extraction process of palm oil). The conversion routes of palm oil biomass to bioenergy involved in both the upstream and downstream sectors as presented in Figure 1.

The aim of this paper is twofold. Firstly, is to examine what are the challenges and what could be achieved if Malaysia were to apply a principles based approach similar to the UKBS in its current bioenergy policy. Secondly, is to assess in general based on existing literatures, the sustainability of bioenergy with reference to the use of palm oil biomass (hereinafter referred to as 'palm oil bioenergy') by adopting the principles governing bioenergy policy in the UK (or the UK Bioenergy Strategy (UKBS) [3]). To this aim, the paper discusses on some of the 
technical aspects and issues relating to the sustainability of palm oil bioenergy, in correlation to the UK sustainability criteria for bioenergy and biomass based on GHG emission and land use criteria. This paper however is not intended to discuss or provide an exhaustive account on all energy policy and energy-related programmes implemented in Malaysia, but rather limited within the scope of bioenergy in its current policy.

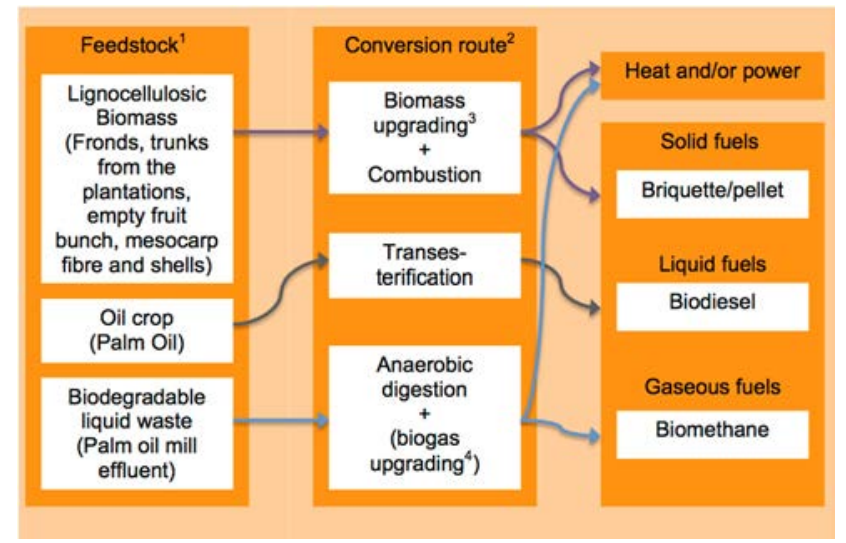

Figure 1: Schematic view of commercial palm oil biomass routes (modified from IEA [8]). Notes: ${ }^{1}$ parts of each feedstock, ${ }^{2}$ each routes also gives co-products, ${ }^{3}$ biomass upgrading include one of the densification processes (e.g. briquetting, pelleting), ${ }^{4}$ anaerobic digestion processes releases methane $\left(\mathrm{CH}_{4}\right)$, and removal of $\mathrm{CO}_{2}$ provides essentially methane, the main component of natural gas; the upgraded gas is called biomethane.

\section{UK sustainability criteria for biomass}

Life Cycle Assessment is a well-established process to quantify the total environmental effects of a product or service, by considering all processes involved, from the production of raw material, to the final use or disposal of products (also known as ‘cradle to grave’ analysis). The environmental impact can be quantified into several categories, including total primary energy requirement and GHG emissions. In the case of GHG emissions, carbon dioxide is used as a reference to quantify these impacts [9]. Besides lifecycle GHG emissions, the sustainability of bioenergy is also influenced by land and biomass resource management practices. Changes in land and forest use or management, according to a considerable number of studies, can contribute to Direct and Indirect Land Use Change (DLUC and ILUC) driven by bioenergy feedstock production, which can decrease or increase terrestrial carbon stocks. DLUC occurs when bioenergy feedstock production modifies an existing land use, resulting in a change in above and below ground carbon stocks. ILUC occurs when a change in production level of an agricultural product (i.e. a reduction in food or feed production induced by 
agricultural land conversion to produce a bioenergy feedstock) leads to a marketmediated shift in land management activities (i.e. DLUC) outside the region of primary production expansion [10]. While the significance of land use and DLUC effects are reflected in most LCA studies [51], ILUC however, is not directly observable and is complex to model and difficult to attribute to a single cause as multiple actors, industry, countries, policies and markets dynamically interact. This is also as in the case of the exclusion of ILUC in the calculation of GHG emission savings for biofuels and bioliquid in the European Union Renewable Energy Directive (EU RED).

The UK recognises two sets of biomass for its sustainability criteria assessment (life cycle GHG emission and land use criteria) as presented in Table 1. The first biomass type is solid and gaseous biomass used in electricity and/or heat generation and secondly, biofuels and bioliquids used as liquid transport fuel. The sustainability criteria for the former biomass was set by the UK Government under the Renewables Obligation (RO) [11]; and the latter under Article 17 of the EU RED [12].

Table 1: Sustainability criteria for biomass use in energy generation.

\begin{tabular}{ll}
\hline & \multicolumn{1}{c}{ Solid and gaseous biomass } \\
\hline $\begin{array}{l}\text { GHG emission } \\
\text { savings }\end{array}$ & $\begin{array}{l}\text { Minimum 60\% GHG lifecycle emission saving for } \\
\text { electricity generation using solid biomass or biogas } \\
\text { relative to fossil fuel }\end{array}$ \\
\hline $\begin{array}{l}\text { General } \\
\text { restrictions } \\
\text { on land use }\end{array}$ & $\begin{array}{l}\text { Materials sourced from land with high biodiversity value } \\
\text { or high carbon stock, including primary forest, protected } \\
\text { areas, peatlands and wetlands (during or after January } \\
\text { 2008) }\end{array}$ \\
\hline $\begin{array}{l}\text { GHG emission } \\
\text { savings }\end{array}$ & $\begin{array}{l}\text { Minimum 35\% GHG lifecycle emission saving relative } \\
\text { to fossil fuel; increasing to 50\% in 2017 and 60\% for new } \\
\text { installations in 2018 }\end{array}$ \\
\hline $\begin{array}{l}\text { General } \\
\text { restrictions on land } \\
\text { use }\end{array}$ & $\begin{array}{l}\text { Raw materials from land important for biodiversity or a } \\
\text { carbon sink }\end{array}$ \\
\hline
\end{tabular}

\section{Discussions}

\subsection{Bioenergy support policy and programmes}

In the broader context of bioenergy, sustainability criteria is related to environmental, social or economic conditions used to distinguish between desirable and undesirable forms of bioenergy [13]. Government policies are widely recognised as one of the factors which affect how biomass is used in the energy system. The UKBS sets out a framework by taking a principles based approach in setting a strategic direction to guide bioenergy policy. It aims to ensure that its policies only support bioenergy use in the right circumstances; which is in 
a way that bioenergy secures its benefits while managing the challenges connected to bioenergy-related risks and uncertainties. The associated risks arise as there are for instance, potential indirect impacts of bioenergy on land use that can significantly change the carbon stored in land across the world. In addition, poor resource management can lead to significant environmental, social and economic impacts that could outweigh bioenergy's wider energy benefits [3]. The UKBS also highlights the issues on some of these technical aspects arising from two of its principles (Annex B of the strategy).

To achieve UK's energy security and carbon reduction objectives, the UK is legally committed to meet its $15 \%$ energy demand from renewable sources by 2020. In order to increase and accelerate the use of renewable energy, the Department of Energy and Climate Change has introduced a number of policies [14] including the Renewables Obligations (RO), FiT scheme and the Renewable Transport Fuel Obligation (RTFO). Unlike the UK, there is no systematic framework governing Malaysia’s bioenergy policy. Bioenergy policy in Malaysia (i.e. to promote the production and use of renewable electricity and liquid transport fuel (biodiesel)) is either introduced as part of an energy policy plan through a specific Act (i.e. Renewable Energy Act 2011 and Malaysian Biofuel Industry Act 2007) or through energy or climate mitigation programmes. The formation and implementation of bioenergy policy involves the Ministry of Energy, Green Technology and Water, the Ministry of Plantation Industries and Commodities, and two units under the Prime Minister's Department: Economic Planning Unit and the Performance Management and Delivery Unit. Some of the bioenergy support policies both in the UK and Malaysia are presented in Table 2.

The main principle governing the UK bioenergy policy is to support bioenergy that deliver 'genuine carbon reductions' that help meet UK carbon emission objectives to 2050 and beyond. Financial incentives is given for bioenergy such as the RO and RTFO. Adopting a similar policy in Malaysia could boost up the palm oil biomass industry especially in promoting the market for high quality biofuels, such as pre-treating empty fruit bunch (EFB), the most underutilised solid biomass generated in the palm oil mills. EFB treatment plant can produce dry long fibre; which is sold commercially in the baled form as boiler fuels, and palm biomass briquettes and pellets; as alternative to fossil fuels for use in biomass-based power plant and co-generation [15]. In addition, this will also create a market for biogas generated from POME, to be sold as compressed natural gas, or the potential production of second generation biofuels such as hydrogen and biomethane in the future.

The UK FiT scheme however, has a different implementation setting than the FiT scheme in Malaysia. The UK FiT pays a tariff not only for the electricity exported to the grid, but also pays a tariff for the electricity which is generated. A similar implementation in Malaysia will most likely benefit the palm oil mills who have been producing electricity for in-house use (e.g. electricity/heat for ancillary processing in mills or facilities or refinery within close proximity to the plant). In 2013, it was estimated that a 395 MW off-grid electricity (based on 428 mills and 92.33 million tonnes of fresh fruit bunches processed at $20 \mathrm{kWh} /$ tonne [16]) was generated to support such activities. 
Table 2: Some of the bioenergy support policies in the UK and Malaysia.

\begin{tabular}{|c|c|}
\hline Policy & Purpose \\
\hline \multicolumn{2}{|r|}{ UK } \\
\hline Feed-in-Tariff & $\begin{array}{l}\text { The FiT scheme is implemented to promote the } \\
\text { uptake of a range of small-scale renewable and low } \\
\text { carbon electricity generation technologies using solar } \\
\text { photovoltaic, wind, hydro and anaerobic digestion } \\
\text { (total installed capacity of } 5 \mathrm{MW} \text { or less), and micro } \\
\text { combined heat and power (total installed capacity of } \\
2 \mathrm{~kW} \text { or less). FiT pays a tariff for the electricity } \\
\text { generated and tariff for the electricity exported to the } \\
\text { grid. }\end{array}$ \\
\hline $\begin{array}{l}\text { Renewables } \\
\text { Obligation }\end{array}$ & $\begin{array}{l}\text { The RO is the main support mechanism for } \\
\text { renewable electricity projects in the UK. The RO } \\
\text { incentivises renewable generation into the electricity } \\
\text { generation market by enabling operators (generating } \\
\text { stations with a declared net capacity of greater than } \\
50 \mathrm{~kW} \text { ) to be awarded with renewables obligation } \\
\text { certificates (ROCs). }\end{array}$ \\
\hline $\begin{array}{l}\text { Renewable Transport } \\
\text { Fuel Obligation }\end{array}$ & $\begin{array}{l}\text { The RTFO is aim to encourage the production of } \\
\text { sustainable biofuels by allowing suppliers (who } \\
\text { supplies at least } 450,000 \text { litres of fuel a year) of } \\
\text { transport and non-road mobile machinery fuel with a } \\
\text { percentage of fuel coming from renewable and } \\
\text { sustainable sources to claim Renewable Transport } \\
\text { Fuel Certificates (RTFCs). }\end{array}$ \\
\hline \multicolumn{2}{|r|}{ Malaysia } \\
\hline Feed-in-Tariff & $\begin{array}{l}\text { The FiT scheme is implemented with the aim to lead } \\
\text { renewable electricity from renewable energy } \\
\text { (biomass, mini-hydro and solar photovoltaic) to a } \\
\text { higher share in the power generation mix. The FiT } \\
\text { system obliges the Distribution Licensees to buy } \\
\text { renewable electricity which is supplied to the } \\
\text { electricity grid at a certain tariff. }\end{array}$ \\
\hline EPP5 & $\begin{array}{l}\text { The Entry Point Projects No. } 5 \text { (EPP5) is } \\
\text { implemented under the Palm Oil National Key } \\
\text { Economic Area to promote renewable electricity } \\
\text { generation through biogas trapping/recovery from } \\
\text { POME. }\end{array}$ \\
\hline B5 Programme & $\begin{array}{l}\text { B5 Programme is a mandatory blending requirement } \\
\text { of } 5 \% \text { palm based biodiesel (methyl ester) and 95\% } \\
\text { diesel. The programme requires up to 500,000 tpa } \\
\text { biodiesel. }\end{array}$ \\
\hline
\end{tabular}


The UK bioenergy policy, where legally possible, are also accompanied by the requirement for reporting on the sustainability assessment. The reporting system (e.g. in RO and RTFO) involve the calculation of GHG emissions from the whole life cycle of the feedstock development and combustion (i.e. GHG emission savings from the use of the biomass to generate one mega joule of electricity in the RO, and GHG emission savings of biodiesel in relative to fossil fuel in the RTFO), and type of land on which the biomass is produced (during or after January 2008), and applies to the use of both imported and domestic biomass and biogas for electricity generation, and biodiesel as transport fuel.

\subsection{Sustainability criteria for bioenergy}

In order to assess the sustainability criteria of bioenergy, biomass is categorised under two types of biomass; solid and gaseous biomass, and biofuels and bioliquids. In order to assess the sustainability of palm oil bioenergy, palm oil biomass need to be treated according to the 'type' of biomass adapted from the UK classification of biomass. Table 3 summarises the biomass category/type, the requirement in the sustainability assessment reporting system and the classification of palm oil biomass based on definition given in the references.

Table 3: Biomass category/type in the UK bioenergy and palm oil biomass.

\begin{tabular}{|c|c|c|c|}
\hline \multicolumn{4}{|c|}{ UK bioenergy } \\
\hline $\begin{array}{l}\text { Biomass category/ } \\
\text { policy }\end{array}$ & $\begin{array}{l}\text { Biomass type/ } \\
\text { Example }\end{array}$ & $\begin{array}{c}\text { Lifecycle GHG emission } \\
\text { savings }\end{array}$ & Land use \\
\hline \multirow[t]{2}{*}{$\begin{array}{l}\text { Solid and gaseous/ } \\
\text { RO Reporting } \\
\text { Requirement }\end{array}$} & $\begin{array}{l}\text { Agriculture residue } \\
\text { (e.g. straw, bagasse, } \\
\text { husks, cobs and nut } \\
\text { shells) and } \\
\text { processing residue } \\
\text { (e.g. crude } \\
\text { glycerine) }\end{array}$ & $\begin{array}{l}\text { Emission during and from } \\
\text { the process of collection }\end{array}$ & $\begin{array}{l}\text { Required for } \\
\text { reporting }\end{array}$ \\
\hline & $\begin{array}{l}\text { Waste/wholly } \\
\text { derived from waste }\end{array}$ & Exempted from reporting & $\begin{array}{l}\text { Exempted from } \\
\text { reporting }\end{array}$ \\
\hline $\begin{array}{l}\text { Biofuels and } \\
\text { bioliquids/ } \\
\text { RTFO }\end{array}$ & $\begin{array}{l}\text { e.g. Biodiesel } \\
\text { (i.e. methyl ester) }\end{array}$ & $\begin{array}{l}\text { Emission up to the process of } \\
\text { collection including during } \\
\text { its cultivation }\end{array}$ & $\begin{array}{l}\text { Criteria } \\
\text { required }\end{array}$ \\
\hline \multicolumn{4}{|c|}{ Malaysia palm oil bioenergy } \\
\hline Biomass category & Biomass type & Palm oil biomass & Reference \\
\hline \multirow[t]{2}{*}{ Solid and gaseous } & $\begin{array}{l}\text { Agriculture residue } \\
\text { and processing } \\
\text { residue }\end{array}$ & $\begin{array}{l}\text { Agriculture residue: fronds } \\
\text { and trunks } \\
\text { empty fruit bunch, mesocarp } \\
\text { fibre, shells } \\
\text { Processing residues: } \\
\text { briquettes, pellets }\end{array}$ & {$[17]$} \\
\hline & $\begin{array}{l}\text { Waste/wholly } \\
\text { derived from waste }\end{array}$ & POME & {$[18,19]$} \\
\hline $\begin{array}{l}\text { Biofuels and } \\
\text { bioliquids }\end{array}$ & Biodiesel & Palm based methyl ester & \\
\hline
\end{tabular}


Such requirement for a sustainability assessment of biomass in the reporting system would imply that information on lifecycle GHG emission during and from the process of collection of biomass is needed for palm oil 'agriculture and processing residue' such as fronds, trunks empty fruit bunch, mesocarp fibre, shells, briquettes and pellets and lifecycle GHG emission up to the process of collection of biodiesel feedstock including during its cultivation for palm based biodiesel. If a similar policy is to be applied in Malaysia, sustainability assessments by palm oil smallholders especially independent smallholders is nearly impossible to be taken into account. This is as smallholders often lack the knowledge, finances, and overall capacity needed to fulfil such requirements nor to provide such input which is needed to conduct a lifecycle assessment. Thus, any benefits and incentives for such programme will have to discredit participation of smallholders, which accounts to $40 \%$ holding from the total palm oil planted area.

In terms of the life cycle GHG emission savings for palm based biodiesel, recent studies showed that it could have similar life cycle GHG emissions savings as rapeseed and soybean based biodiesel if the palm plantation is properly managed and biogas release from POME is captured [20-23]. The GHG emission savings reported varies from $35 \%$ to $66 \%$, using methodology which takes into account alternate co-product use [23], crops on tropical fallow land, use of crop residue to power generation, and with good management [24]. The EU RED has set typical and default values for the calculations of life cycle GHG emission savings for palm oil biodiesel (process unspecified) at 36\% and 19\% respectively, and for palm oil biodiesel (which process involves methane capture at palm oil mill) at $62 \%$ and $56 \%$ respectively [12]. This would mean that based on the default values, biodiesel using palm oil as biodiesel feedstock when produced in a process which involves the capture of methane from POME, qualifies as 'sustainable' under the criteria of 'a minimum 35\% GHG lifecycle emission savings', and remain qualifies as 'sustainable' in 2017, when the minimum GHG lifecycle emission savings requirement is increased from $35 \%$ to $50 \%$. The EU RED default value for palm oil biodiesel which process involves the capture of methane at palm oil mill also showed the highest GHG emission savings compared to other biodiesel feedstocks, which are soybean, rape seed and sunflower oils which GHG emission savings are $31 \%$, 38\%, and 51\% respectively [12].

Thus, only biodiesel from palm oil feedstock with process specified above, and when in accordance with the general restrictions on land criteria/land use, complies with the sustainability criteria for bioenergy in the UK. The Roundtable of Sustainable Palm Oil (RSPO)-RED certified biodiesel is an example of sustainable biodiesel for the European biofuels market. The Malaysian palm oil sector plays an active participation in the RSPO, with 1.05 million hectare production area certified or $41 \%$ from the total 2.55 million hectare RSPO certified production area. Malaysia also supplies $44 \%$ from the total RSPO certified sustainable palm oil [25].

Sustainability criteria in terms of land use would also mean that bioenergy feedstocks should not be sourced from land (during or after January 2008) with high biodiversity value or high carbon stock, including primary forest, protected areas, peatlands and wetlands. This also implies that an area of 4.3 million hectares, 
which is already planted with palm oil in January 2008 is accorded as in compliance with the general restrictions on land use criteria. In terms of palm oil expansion in West Malaysia, most of the land alienated for palm oil cultivation have been allocated and planted, thus expansion areas mostly occur on marginal land. Producers have been moving their operations from West to East Malaysia, but there too, the best land have been delineated and mostly planted. As such, with the exception of the East Malaysian state of Sarawak, palm oil expansion can no longer be supported in new areas, hence new developments are thus shifting more to the marginal areas with poorer soils, terrain and rainfall [26], and by replacing other less profitable crops (coconut, rice, rubber and cocoa) and on logged-over forests [27-28].

New palm oil planting areas for post January 2008 such as those recorded in the state of Sarawak, involving new planting on 84,660 hectares in 2013 [29], and its future expansion plan will require complex monitoring of land use including any plantings on peatland if it is to meet the UK sustainability criteria. According to the RSPO-RED certification, plantings on peatland can only be certified if the land was already under palm oil cultivation in January 2008, and if there is evidence that the production of palm oil does not involve drainage of previously undrained soil. If the land was partially drained in January 2008, subsequent deeper drainage affecting soil that was not already fully drained is not allowed under the RSPO-RED. In practice, it will be very difficult, if not, impossible to certify plantings on peatland against the RSPO-RED certification requirements [30]. In the meantime, a sustainable approach to palm oil expansion thus applies on degraded land as this can relieve the pressure on land with sensitive ecosystems such as peatland, in addition to the ability of palm oil planted on degraded land to function as a carbon sink [23]. The use of degraded land for palm oil production may result in lower yields, but the actual reduction depends strongly on the type of the degraded land and the severity of the degradation [31].

\section{Conclusions}

The sustainability of solid and gaseous oil palm biomass used for renewable electricity generation depends highly on the calculation of life cycle GHG emission during and from the process of biomass collection as GHG emission up to the point of collection are considered to have zero emission. On the other hand, the sustainability of biofuels and bioliquids such as palm based biodiesel depends highly on the process in which palm oil (biodiesel feedstock) is produced, in particular in process which involves biogas capture from the POME. The future challenges for oil palm biomass sustainability with regard to land use criteria include biomass from new planting areas in East Malaysia. In conclusion, the principles governing the bioenergy policy in the UK suggests that the 'bioenergy sustainability' is generally assessed from the environmental aspects to produce 'genuine carbon reductions'. In order for Malaysia to adopt a similar sophisticated principles based approach, the challenges towards bioenergy sustainability lies on how to manage the trade-offs between the environmental, social and economic dimensions of the bioenergy sector. 


\section{References}

[1] UNDP Human Development Report 2007/2008: Fighting Climate Change. New York: UNDP; 2007.

[2] Malaysia's Second National Communication to the UNFCCC. Putrajaya: Ministry of Natural Resources and Environment; 2009.

[3] UK Bioenergy Strategy. Department of Energy and Climate Change; 2012.

[4] Annual Report 2013. Sustainable Energy Development Authority Malaysia. Softcopy version accessed on 2 September 2014. (http://seda.gov.my)

[5] Goh C.S., Tan K.T., Lee K.T, and Bhatia S. Bio-ethanol from lignocellulose: Status, perspectives and challenges in Malaysia. Bioresource Technology, 2010; 101: 4834-4841.

[6] MPOB (http://bepi.mpob.gov.my).

[7] National Biomass Strategy 2020: New Wealth Creation for Malaysia’s Palm Oil Industry. Kuala Lumpur: Agensi Inovasi Malaysia-MIGHT; 2011.

[8] IEA Bioenergy - A Sustainable and Reliable Energy Source: Main Report. IEA Bioenergy; 2009.

[9] Life Cycle Assessment. Royal Society for Chemistry; 2010. Document available online:

http://www.rsc.org/ScienceAndTechnology/Policy/EHSC/EHSCnotesonLi feCycleAssessment.asp

[10] Summary for Policymakers. In: IPCC Special Report on Renewable Energy Sources and Climate Change Mitigation [O. Edenhofer, R. Pichs-Madruga, Y. Sokona, K. Seyboth, P. Matschoss, S. Kadner, T. Zwickel, P. Eickemeier, G. Hansen, S. Schlömer, C. von Stechow (eds)], Cambridge University Press: Cambridge, United Kingdom and New York, NY, USA; 2011.

[11] Renewables Obligations: Sustainability Criteria for Solid and Gaseous Biomass for Generators (greater than 50 kilowatts). Ofgem; 2011.

[12] Directive 2009/28/EC of the European Parliament and of the Council on the Promotion and Use of Energy from Renewable Sources.

[13] The broad issue of sustainability is discussed inter alia at an IEA workshop on bioenergy, in May 2010.

[14] DECC (https://www.gov.uk/government/policies/increasing-the-use-oflow-carbon-technologies).

[15] National Key Economic Areas: National Biogas Implementation (EPP5) Biogas Capture and CDM Project Implementation for Palm Oil Mills, PEMANDU Report; 1 January 2013.

[16] Bakar N.A. Country Presentation Status in Bioenergy Development in Malaysia. South-East Asia Expert Workshop on Biomass resources and Bioenergy potential - How2Guide for Bioenergy. International Energy Agency, Thailand; 2014.

[17] UK Bioenergy Strategy. Department of Energy and Climate Change; 2012. See Communication from the Commission on the practical implementation of the EU biofuels and bioliquids sustainability scheme and on counting rules for biofuels 2010/C 160/02, European Commission; 19/06/2010. 
[18] Ibid. See section 75(2) of the Environmental Protection Act 1990.

[19] Ibid. See section Waste and Contaminated Land and (Northern Ireland) Order 1997.

[20] Beer, T., and Grant, T. Life-cycle analysis of emissions from fuel ethanol and blends in Australian heavy and light vehicles. Journal of Cleaner Production, 2007:15(8-9): 833-837.

[21] Well-to-wheels Analysis of Future Automotive Fuels and Powertrains in the European Context. Conservation of Clean Air and Water in Europe (CONCAWE), Brussels: 2007.

[22] Hoefnagels, R., Smeets E., and Faaij, A. Greenhouse gas footprints of different biofuel production systems. Renewable and Sustainable Energy Reviews, 2010, 14(7): 1661-1694.

[23] Wicke, B., Dornburg, V., Junginger, M. and Faaij, A. Different palm oil production systems for energy purposes and their greenhouse gas implications. Biomass and Bioenergy, 2008, 32(12): 1322-1337.

[24] Reinhardt, G.A, and von Falkenstein, E. Environmental assessment of biofuels for transport and the aspects of land use Competition. Biomass and Bioenergy, 2011, 35: 2315-2322.

[25] RSPO (http://www.rspo.org/en/Market_Data_-_As_at_31st_July_2014).

[26] Ming, K.K., Chandramohan, D. Malaysian Palm Oil Industry at crossroads and its future direction. Oil Palm Industry Economic Journal, 2002: 2(2): 10-15.

[27] Choo, Y.M., Muhamad, H., Hashim, Z., Subramaniam, V., Puah, C.W., Tan, Y.A. Determination of GHG contributions by subsystems in the oil palm supply chain using the LCA approach. The International Journal of Life Cycle Assessment, 2011; 16: 669-681.

[28] Wicke, B., Sikkema, R., Dornburg, V., and Faaij, A. Exploring land use changes and the role of palm oil production in Indonesia and Malaysia. Land Use Policy, 2011; 28: 193-206.

[29] Overview of the Malaysian Oil Palm Industry 2013. MPOB (http://bepi.mpob.gov.my/images/overview/Overview_of_Industry_2013. pdf).

[30] RSPO (http://www.rspo.org/file/FAQ\%20on\%20RSPO-RED_7March(1). pdf).

[31] Corley, R.H.V. and Tinker, R.B.H., The Oil Palm. Blackwell Publisher: Oxford; 2003: 592. 